\title{
Political realities of statewide smoking legislation: the passage of California's Assembly Bill 13
}

\author{
Heather R Macdonald, Stanton A Glantz
}

\begin{abstract}
Objective-To prepare a history of the enactment of California Assembly Bill 13 (AB 13), a state law prohibiting smoking in most workplaces passed in 1994, and to discuss its initial impacts.

Methods-Data were gathered from open ended interviews with representatives of voluntary health organisations, local government organisations, and principal legislators involved in the process, as well as observers around the state who could provide insight into the legislative process. Information was also obtained from legislative hearings and debates, public documents, letters and personal communications, internal memoranda, and news reports.
\end{abstract}

Results-The success of local tobacco control legislation in California led to a situation in which some health groups were willing to accept state preemption in order to attract the support of the state restaurant association for a bill. The decision to accept this preemption compromise was made by the state level offices of the voluntary health agencies without consulting the broader tobacco control community within California. In contrast, local tobacco control advocates did not accept this compromise, in part because of their belief that local legislation was a better device to educate the public, generate media coverage, and build conmunity support for enforcement and implementation of clean indoor air and other tobacco control laws. Enactment of AB 13 was associated with a slowing of all local tobacco control legislation, including youth oriented laws.

Conclusions-Because its supporters initially doubted that AB 13 would pass, there was never an effort to reconcile the policy differences between state oriented and locally oriented tobacco control policies. This lack of consensus, combined with the political realities inherent in passing any state legislation, led to a bill with ambiguous preemption language which replaced the "patchwork of local laws" with a "patchwork of local enforcement."

\section{(Tobacco Control 1997;6:41-54)}

Keywords: tobacco control legislation; California; Assernbly Bill 13
When the non-smokers' rights movement first developed in the United States in the 1970s, tobacco control advocates could not pass state laws restricting tobacco use because of the infiuence the tobacco had in state governments, ${ }^{1}$ so they turned to pursuing local ordinances. The strategy of passing local ordinances used the organisational strengths of local tobacco control advocates as well as the weaknesses of the tobacco industry. ${ }^{2}$ The success of this local strategy was evident by the increasing number of local ordinances passed between 1977 and 1994, a trend that accelerated in response to the 1992 US Environmental Protection Agency (BPA) report that identified environmental tobacco smoke as a "class A" (known human) carcinogen. ${ }^{34}$ The tobacco industry's primary strategy to oppose local ordinances and protect its interests has been to enact weak, unenforceable state laws that preempt or disallow local ordinances regulating smoking. ${ }^{5-8}$ As of January 1996, 18 states had preempted local clean indoor air laws and preemption language in some form has been considered in tobacco cortrol legislation in every state in the nation. ${ }^{10}$

In California, as a resuit of local activity, by 1993 nearly two thirds of workers were protected by local laws mandating $100 \%$ smoke-free workplaces, and $87 \%$ worked with some restriction on workplace smoking ${ }^{4} 11-13$ (fig 1). Additionally, the passage of a tobacco tax ballot initiative in 1988, Proposition 99, and the anti-tobacco education campaign it funded, raised public awareness about the health dangers of passive smoking and stimulated the development of local tobacco control coalitions throughout the state. ${ }^{14}$ These local tobacco control coalitions used the issue of clean indoor air to mobilise the general public to support a broader tobacco control agenda. ${ }^{15}$

The success of local tobacco control legislam tion in California led to a situation in which some health groups were willing to accept state preemption in order to attract the support of the state restaurant association for a bill, Assembly Bill 13 (AB 13), which mandated $100 \%$ smoke-free workplaces. The decision to accept this preemption compromise was made by the state level offices of the American Heart Association, the American Cancer Society, and the American Lung Association without consulting the broader tobacco control community within California. ${ }^{16}$ In contrast, 


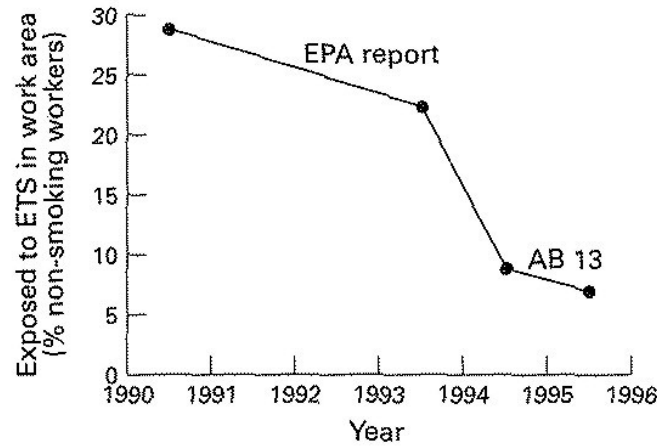

Figure 1 Fraction of Californians employed indoors outside the home who report exposure to environmental tobacco smoke (ETS) at work. ${ }^{41+3,36} A B 13$ did nor speed the trend towards smoke-free workplaces in California.

local tobacco control advocates, whose interests were represented by Americans for Nonsmokers' Rights, did not accept this compromise, in part because of a belief that local legislation was a better device to educate the public, generate media coverage, and build community support for enforcement and implementation of clean indoor air and other tobacco control laws. ${ }^{17} 18$ Because its supporters initially doubted that $A B 13$ would pass, there was never an effort to reconcile these policy differences between state oriented and locally oriented tobacco control policies. This lack of consensus, combined with the political realities inherent in passing any state legislation, led to a bill with ambiguous preemption language and replaced the "patchwork of local laws" with a "patchwork of local enforcement."

\section{Methods}

Data for this case study were gathered from taped open ended interviews with 22 representatives of voluntary health organisam tions, local government organisations, and principal legislators involved in the process, as well as observers around the state who could provide insight into the legislative process. Information was also obtained from legislative hearings and debates, public documents, letters and personal communications, internal memoranda, and news reports.

All key informants were allowed to review and comment on a draft of the manuscript; we invited comments on accuracy of our representation of events as well as comments on our interpretation of those events. These comments were used in preparing the final manuscript for submission.

Data on passage of local ordinances were obtained from Americans for Nonsmokers' Rights (Berkeley, California) database of local ordinances. Data on prevalence of environmental tobacco smoke exposure in workplaces were obtained from the California tobacco surveys conducted by the California Department of Health Services. ${ }^{11219}$

Our study has two main methodological limitations. The tobacco industry declined to be interviewed. ${ }^{20}$ Instead, a tobacco industry perspective was provided by the staff of legislators who are supportive of tobacco industry positions, public statements by business organisations of which the tobacco industry is a member, and by observations of tobacco control advocates and others knowledgeable about tobacco industry activities in opposition to smoking restriction legislation. Likewise, Assemblyman Curtis Tucker (Democrat from Ingelwood), who carried the tobacco industry's competing bill, refused to be interviewed.

The bill's author, Terry Friedman (Democrat from Santa Monica), declined to participate in the study. Friedman's staff stated they would only answer written questions. ${ }^{21}$ After another request for an interview, Friedman answered he would only grant the interview if he was provided with transcripts of interviews with other participants with their permission. ${ }^{22}$ When this request was declined, Friedman and his staff returned written questions unanswered. Thus his perspective is not directly included. However, by relying upon interviews with key supporters, written communication between Friedman and the coalition provided by coalition members, and written communication between Friedman and the case study authors, we believe we represented Friedman's activities and perspective.

Another limitation of this study is the fact that one of the authors (Glantz) was identified with the strategy of local ordinances for controlling tobacco use. ${ }^{23}$ This author also had relationships with several of the organisations that were protagonists on both sides of the debate over $A B 13$. He served as an officer of Americans for Nonsmokers' Rights from 1981 to 1986 (at which time he left the board) and acted as an informal consultant to Americans for Nonsmokers' Rights, the American Heart Association, and the American Lung Association during the period covered by this paper.

\section{Results}

FRIEDMAN'S EARLY ATTEMPT TO PASS \$TATE CLEAN INDOOR AIR LEGISLATTION

In February 1992, Assembly member Terry Friedman introduced a non-preemptive statewide clean indoor air law, Assembly Bll 2667 (AB 2667), to prohibit smoking in al enclosed workplaces. Friedman promoted the bill as an alternative to local tobacco control ordinances. ${ }^{24}$ Because $\mathrm{AB} 2667$ dealt with labour law, Friedman designated the Californis Occupational Safety and Health Administrat tion (Cal/OSHA) in the state Department of Industrial Relations, as opposed to the Depart ment of Health Services, to be the enforcement agency. The voluntary health organisations American Lung Association, American Hearl Association, and American Cancer Societyl supported $\mathrm{AB} 2667,{ }^{25}$ as did the Californit Medical Association ${ }^{26}$ and California Labo Federation (AFL-CIO). Despite its lack 2 enthusiasm for state legislation on clean indoor air issues, the national non-smokers' rights activist group, Americans for Nonsmokers Rights (ANR), also expressed support for Friedman's efforts so long as his bill did nol contain language that preempted local ordinances. ${ }^{27}{ }^{28}$ In any event, the chance thi 
the bill would pass was considered very low, because, in addition to the tobacco industry, other traditional opponents of tobacco control-particularly the hospitality and tourism industries-m-were unlikely to allow the bill to go forward. Neither the stare level voluntary health agencies nor ANR (and other supporters of the local ordinance approach) saw any practical reason to engage in broad consultation over the desirability of a state law versus simply continuing to concentrate on local ordinances, much less a discussion of the conditions under which state preemption of local ordinances would be an acceptable compromise to obtain a state smoke-free workplace law.

The prospect of enacting statewide workplace smoking legislation improved dramatically when Friedman negotiated support for his bill from the California Restaurant Association (CRA). The CRA was concerned abour increasing scientific evidence that linked environmental tobacco smoke with illness and the threat of workers compensation and Americans with Disabilities Act claims for tobacco induced diseases. ${ }^{30}$ Before the introduction of $A B$ 2667, the CRA board had taken the position that there should be a single statewide standard regulating smoking in all public places, including restaurants, and that the CRA would continue to oppose local ordinances due to business concerns about unfain competition. ${ }^{31}$ CRA general counsel Jo-Linda Thompson explained the need for a single state rule saying, "The 200 local ordinances are inconsistent. We want one rule that everyone understands." 32

The CRA made its support of Friedman's state legislation conditional on inclusion of preemption of local ordinances. ${ }^{33}$ Subsequently, to attract CRA support for his bill, Friedman amended $\mathrm{AB} 2667$ to include a preemption provision that would:

sapersede and render umecessary the local enactment ot enforcement of local ordinances regulating the smoking of tobacco products in enclosed places of employment [section 2(c)] ${ }^{3 / 4}$

The CRA endorsed the amended bill. ${ }^{33}$ This was the first time an important business lobby in Sacramento (the state capital) had supported tobacco control legislation, and the CRA was viewed as an important addition to the coalition of health groups supporting $A B$ $2667 .^{3536}$

By continuing to support AB 2667 after it was amended, the state voluntary health agencies had adopted a position that conflicted with their national organisations" policy against preemption. In 1989, in response to a growing number of states where the tobacco industry had proposed and enacted preemptive state legislation, the national voluntary health agen cies, acting through the Coalition on Smoking OR Health, took a strong anti-preemption position. ${ }^{37}$ It recommended to the voluntary health agencies" affliates seeking state tobacco control legislation that: it is better to have no law than one that elminates a local government body's authority to act to protect the public health. ${ }^{37}$

If a preemptive bill or preemption amendment was introduced, no matter how friendly to the health groups' interests, the national coalition suggested that affiliates inform the legislator, that:

unless the preemption is removed from the bill that your organisation can no longer support the bill. ${ }^{37}$

Despite this clear national policy to the contrary, the state voluntary health organisations and Friedman defended the preemption language by arguing that the bill would make all workplaces $100 \%$ smoke-free, so no local community could legislate a weaker standard, and the preemption was a moot issue. ${ }^{38-40}$

Rather than opposing the bill, ANR took a neutral position, stating their opposition to the preemption clause and raising concerns regarding Cal/OSHA's ability to actively enforce the law. ${ }^{4]}$ As before, however, no one called for a direct discussion of the public policy implications of accepting preemption or pushing for a state law or what other compromises would be acceptable, probably because $\mathrm{AB} 2667$ was still viewed as unlikely to pass.

$\mathrm{ANR}$ and the supporters of $\mathrm{AB} 2667$ were, however, concerned that by accepting preemption in principle, it would create a situation in which the tobacco industry would "hijack" the bill and weaken the tobacco control provisions while maintaining the preemption. ${ }^{6}$ In an effort to allay these concerns, Friedman modified the severability clause in the bill to try and limit the preemption in the event the bill was weakened:

In the event this section is repealed or modified by subsequent legislative or judicial action so that the (100 percent) smoking prohibition is no longer applicable to all enclosed places of employment in California, local governments shall have the full right and authority to enact and enforce restrictions on the smoking of tobacco products in enclosed places of employment within their jurisdictions, including a complete prohibition of smoking [section $2(d)]^{34}$

Friedman and the bill's supporters argued that this language would protect local ordinances because should future legislation weaken the smoke-free mandate, the preemption clause would self destruct. ${ }^{36} 42$

In April 1992, Friedman solicited an analysis from the Legistative Counsel (the legislature's legal office) regarding the severability clause. The Legislative Counsel concluded that the severability clause offered no legal protection against future tobacco industry attempts to weaken the smoke-free mandate but maintain the preemption of local ordinances relating to smoking in workplaces because the current session of the legislature had no authority to bind future sessions of the legislature. ${ }^{43}$ The voluntary health agencies continued to support the bill because of its $100 \%$ smoke-free workplace mandate.

Even with the support of the restaurants, labour groups, and voluntary health agencies, 
AB 2667 failed to pass the Labor and Employment Committee in June 1992.

THE BIRTH OF AB 13

Friedman reintroduced $\mathrm{AB} 2667$ as Assembly Bill 13 (AB 13) in the following legislative session in December 1992, and it was assigned to Friedman's Labor and Employment Committee in February 1993. The bill was cosponsored by the CRA, the American Heart Association, AFL-CIO, and the California Medical Association. ${ }^{4}$ The American Heart Association, American Lung Association, and American Cancer Society supported the bill because they wanted smoke-free workplaces. The bill was opposed by groups representing the tourism and hospitality industries and the Tobacco Institute. ${ }^{45}$ In addition, ANR opposed the bill because they objected to preemption. They were also concerned that Cal/OSHA would be a less responsive enforcing agency than local health departments or similar agencies, who enforced many local ordinances. ${ }^{46}$ The anti-tobacco activist group Doctors Ought to Care, ${ }^{47}$ the California State Association of Counties, ${ }^{48}$ and the City of Lodi ${ }^{49}$ also opposed the bill because of the preemption language.

In any event, these differences of opinion still appeared moot. Despite the broadened support for the bill, it was still viewed as unlikely to pass; Dian Kiser, lobbyist for the American Heart Association, wrote her local affiliates, "Frankly, the chance of passage of $A B$ 13, like $A B 2667$, is minuscule." still no formal policy discussion within the California tobacco control community regarding the issue of state versus local legislation or when preemption was an acceptable compromise. Rather than engaging the issue of preemption as a policy issue, supporters of the bill fell back on the argument that since $A B 13$ was " $100 \%$ smoke-free," the issue of preemption was not important.

This difference of interpretation of the preemption language in $\mathrm{AB} 13$ was a constant feature of the debate over the bill. For example, there was no agreement within the legislature concerning the meaning of the preemption language when $\mathrm{AB} 13$ was taken up by Friedman's Labor and Employment commitu tee. On the one hand, the committee analysis, prepared by Friedman's Democratic staff, concluded that $\mathrm{AB} 13$ would only supersede local ordinances as long as the $100 \%$ smoking prohibition was in effect. ${ }^{44}$ On the other hand, the committee's Republican analysis of the bill disagreed and concluded "This act would preempt all local ordinances." ${ }^{350}$ In an effort to address enforcement issues raised by ANR, the bill was amended to designate "appropriate local law enforcement agencies" (police) as the enforcement agency responsible for levying fines for violations. ${ }^{51}$

$A B$ 13, unlike $A B$ 2667, passed out of the Labor and Education Committee. Newspapers credited $\mathrm{AB} 13$ 's passage out of committee to the 1992 EPA report on environmental tobacco smoke $^{3}$ as well as Governor Pete Wilson's decision in early 1993 to end smoking in all state government buildings. ${ }^{45}$
At the first hearing of the Ways and Means Committee, Friedman added two amendments in a continuing effort to respond to concerns about preemption and enforcement. The first clarified the severability clause to ensure that should $A B$ 13's smoke-free mandate be weakened, communities could not only pass and enforce future ordinances but also enforce existing ordinances. Friedman also amended $\mathrm{AB} 13$ to allow local governments to designate a local agency to enforce the law, rather than specifying local police. ${ }^{52}$

While $\mathrm{AB} 13$ was being considered by the Ways and Means committee, the League of California Cities, which had remained neutral on $A B$ 2667, changed its position to support for $\mathrm{AB} 13,{ }^{53}$ on the grounds that the bill would allow local governments to pass restrictions on tobacco in areas the bill did not cover. ${ }^{54}$

THE TOBACCO INDUSTRY'S RESPONSE TO AB 13: ASSEMBLY BILL 996

The tobacco industry pursued several strategies to counter $A B$ 13. First, together with affiliated organisations (including the Southern California Business Association, which listed a registered Philip Morris lobbyist as a board member, ${ }^{55} 56$ and the California Manufacturers Association, of whom Philip Morris was a member ${ }^{57}$ ), it lobbied against the bill on the grounds that $A B 13$ would be detrimental for Californian business. ${ }^{45}$ Second, the tobacco industry tried to have the bill amended to weaken the smoking restrictions, while maintaining the preemption, as it had done successfully in other states. ${ }^{45} 58$ Finally, the tobacco industry proposed a weak preemptive law (AB 996) that would preempt local regulation of smoking, to compete with $\mathrm{AB} 13$.

On 19 April 1993 Assemblymember Curtis Tucker amended $A B 996$ to permit smoking in workplaces when employers met the ventilation standard defined by the American Society of Heating, Refrigerating, and Air Conditioning Engineers (ASHRAE) Standard 62-1989. The ASHRAE standard stated that it was not strict enough to protect workers from environmental tobacco smoke ${ }^{59}$ and because it was already incorporated into most building codes in the state, its inclusion in $\mathrm{AB} 996$ would have allowed smoking in virtually all workplaces. $A B$ 996 also proposed ineffective locking devices to control vending machine cigarette sales to youth, ${ }^{6061}$ and preempted all future tobacco control laws. $A B 996$ was assigned to the Assembly Committee on Governmental Organisation, chaired by Tucker, where it passed by 9 to 0 . The bill was then referred to the Assembly Committee on Ways and Means, where $A B 13$ was being debated.

$\mathrm{AB} 996$ was supported by the tobacto industry and its allies in the business community. ${ }^{62} \mathrm{AB} 996$ was opposed by the sam? coalition of health, local government, and busi ness groups that supported $A B 13$, as well as those who opposed $A B 13$ because of is preemption clause. ${ }^{62}$ The CRA opposed AB 996 because it protected existing local clean indoor air laws with a grandfather clause, so would not lead to a uniform smoking polic 
enforced around the state. ${ }^{30}$ They also feared it would not protect restaurant owners from claims and lawsuits under the workers compensation programme or the Americans with Disabilities Act, and that forcing restaurants to meet the ASHRAE ventilation standards would be prohibitively expensive for small restaurants. ${ }^{30}$

The introduction of $\mathrm{AB} 996$ changed the debate over state smoking restrictions. Before the emergence of $\mathrm{AB} 996$ as a competing bill to $A B$ 13, media coverage of $A B 13$ included the debate among tobacco control advocates over the merits of $A B$ 13, particularly ANR's concern with preemption. ${ }^{63}$ When $A B 996$ started moving in tandem with $A B 13$, media coverage focused on a good bill (AB 13) v a bad bill (AB 996). Supporters of $A B 13$ were successful in garnering support for $\mathrm{AB} 13$ and opposition to $A B, 996$ from newspaper editorial boards all over the state. The fact that $\mathrm{AB} 996$ preempted future local ordinances was an important point in rallying public opposition to the bill. ${ }^{4 t}$ t5 Newspapers described AB 996 as a bill whose real purpose was to prevent local communities from approving their own tough anti-smoking ordinances. ${ }^{\circ 4}$ The policy debate over AB 13's preemption language was overshadowed in the competition between $A B$ 13 and $\mathrm{AB}$ 996; the issue of preemption in $\mathrm{AB}$ 13 ceased to be viewed as worthy of attention by the press. ${ }^{65} 64-31$

THE VEW FRON OUTSDE SACRAMENTO

Controversy over the net effect of $A B$ 13's preemption provisions on local ordinances created confusion among local tobacco control advocates over whether or not to support $A B$ 13. Local coalitions, composed of people from local affliates of the voluntary health agencies, local medical associations, public health agencies, and individual activists, received conflicting information regarding the state debate over AB 13 and $A B$ 996. While opposition to $\mathrm{AB} 996$ was unanimous, the state voluntary health agencies urged support of $A B 13$ while ANR continued to urge opposition. Many individuals who participated in these local coalitions were members of both a voluntary health agency and $\mathrm{ANR}$, and so were receiving action alerts from more than one organisation.

Some activists at the local level questioned the effect $A B 13$ would have on local legislation, ${ }^{38}$ and remained sceptical that a workable bill would emerge from the state legislature. ${ }^{72}$ Of particular concern was the preemption language and its effect on non-workplace provisions of local ordinances, including those mandating public education, or non-tetaliation clauses (which would protect employees who complained about noncompliance with the smoke-free workplace requirement). ${ }^{18}$ Questions from those communities about $A B 13$ were interpreted by lobbyists at the American Lung Association and the American Cancer Society as efforts by ANR to undermine their authority, and they com plained of having to use time and resources responding to what they perceived as ANR's misinterpretation of the bill. ${ }^{30} 40$ ANR viewed its effort as a legitimate way to present its opposition to preemption to the people most affected. ${ }^{27}$

As controversy over the bill intensified, communication broke down between state players, and a hostile exchange emerged with local activists caught in the crossfire. Friedman and members of the $A B 13$ support coalition tried to quieten criticism of $A B 13$ from within California's tobacco control community. For example, in Ventura County, the Ventura Tobacco Control Coalition, drawing on information received from $A N R$, alerted its membership to oppose both $\mathrm{AB} 13$ and $\mathrm{AB}$ 996 because of the preemption language in both bills. ${ }^{73}$ The Ventura Lung Association, a member of the Ventura Coalition, objected to the position because it conflicted with the state branches of American Lung Association, American Heart Association, American Cancer Society, and "all other supporters of Tobacco Control with the exception of ANR". ${ }^{34}$ The authors of the action alert were contacted by both the state office of the American Lung Association and Friedman's office, angered by their opposition to $\mathrm{AB} 13 .^{72}$ As a result, the Ventura coalition sent its nembers an update the following day with an apology to Friedman, and a quote from the League of California Cities stating that since $\mathrm{AB}$ 13's mandate was $100 \%$ smoke-free, the preemption issue was moot. ${ }^{73}$ The net result of the Ventura altercation was a reluctance on the part of local coalitions to involve themselves in the issues surrounding $\mathrm{AB}$ 13. Thus the local activists most likely to be affected by $\mathrm{AB} 13$ were disenfranchised from the policy debate.

Friedman was also publicly critical of members of the tobacco control community who questioned $\mathrm{AB} 13 .^{75}$ Through a series of letters, Friedman initiated a debate between himm self and academic experts in tobacco control, specifically Stanton Glantz (University of California, San Francisco), John Pierce (University of Calfornia, San Diego), John Farquhar (Stanford University), Peter Jacobson (Rand Corporation), and Michael Siegel (US Centers for Disease Control and Prevention). Friedman stated $A B 13$ was not preemptive, saying "AB 13 contains unambiguous anti-preemption language."75 Friedman also questioned the importance of enacting local ordinances in terms of public education and subsequent implementation:

While I understand [the] view that regulation of smoking is best accomplished at the local level, I think thousands of California workers who are currently exposed to environmental tobacco smoke would disagree. That is why [supporters of $A B 13$ ] and I are more concerned about protecting workers health than in the educational process of enacting local ordinances?

Jacobson, ${ }^{2}$ Siegel, ${ }^{78}$ and Pierce ${ }^{79}$ stated that the presence of preemption language in the bill was a serious threat to tobacco control because it had divided tobacco control advocates and legitimised the use of preemption language in future tobacco control legislation. Additionally, Farquhar ${ }^{\text {si }}$ argued that tobacco control 
strategy should emphasise local legislation because local laws "will reach far ahead of any conceivable State laws."

In a public demonstration of the growing conflict among former tobacco control allies, the presidents of the state voluntary health agencies and the California Medical Association circulated a letter warning that "ANR's opposition is unsound and could have dangerous effects." ${ }^{\prime 2}$ This letter was a modified version of a letter originally addressed from Friedman to the American Cancer Society, claiming that ANR authored "a shocking opposition letter which seriously distorts $A B$ 13." 38

$A B 13$ AND AB 996 ON THE ASSEMBL,Y FLOOR $\mathrm{AB} 13$ and $\mathrm{AB} 996$ were considered in tandem by the Assembly Ways and Means Committee. Despite the fact that they were contradictory in intent and effect, both bills passed the Committee, with several members voting for both of them. The bills next moved to the Assembly floor where AB 13 was amended on 24 May 1993 to exempt hotel guest rooms by excluding them from $A B$ 13's definition of a "place of employment." Because $A B 13$ only preempted local regulation of "places of employment," local governments would be permitted to regulate hotel guest rooms.

Both $\mathrm{AB} 996$ and $\mathrm{AB} 13$ came to a floor vote in the Assembly on 1 June 1993, and both failed. Tucker's bill briefly recorded the majority 41 votes needed to pass, but four "aye" votes changed to "no" votes. Assemblyman Tom Umberg (Democrat from Garden Grove), one of the four who changed votes, explained that he did not want $A B 996$ to be the only tobacco bill that passed the Assembly. ${ }^{81}$ Two days later, AB 996 was taken up again, while reconsideration for $A B 13$ was delayed until the following week by $a$ technicality. The tobacco industry's bill, $\mathrm{AB}$ 996 , passed 42 to 34 .

Friedman denounced passage of AB 996 as "an example of the absolutely disgusting power the tobacco industry wields in the legisiature. ${ }^{366}$ The 42 Assembly members who voted for $A B 996$ had received a total of $\$ 964740$ (average $\$ 22970$ per "yes" vote) in tobacco industry campaign contributions during the years 1975 to 1993 , compared to only $\$ 193567$ for the 34 (average $\$ 5693$ per "no" vote) who voted against it. ${ }^{82}$ Newspapers objected to the vote, ${ }^{65838}$ reporting that campaign contributions from tobacco interests to legislators were buying votes against $\mathrm{AB} 13$ and for $A B$ 996. For example, an editorial in the Alameda Times Star stated:

The tobacco industry's preference for state laws coming out of Sacramento rather than more stringent local laws is a sad indication of what it believes it has bought with its generous campaign contributions. $^{70}$

In the debates over local tobacco control ordinances, it had become routine for the tobacco industry, acting through surrogates, to claim that smoking restrictions would cause economic chaos. ${ }^{5-78586}$ The tobacco industry attempted to use the same tactic in the State Legislature; on 6 June 1993, the day after AB 996 passed the Assembly, but before $A B 13$ was reconsidered, several southern California business groups, including the Southern California Business Association-a group with tobacco industry connections-released an economic study by the accounting firm of Price Waterhouse. ${ }^{556}$ (Price Waterhouse conducts negative "economic impact" studies for the tobacco industry throughout the nation.) The study claimed $\mathrm{AB} 13$ would jeopardise 82000 jobs in California and cost the state more than $\$ 3.5$ billion. ${ }^{37}$ It was based on estimates by owners and managers of hotels and restaurants of what business they would lose if a smoking ban went into effect. Of the 127 establishments surveyed, $51 \%$ of restaurants and $45 \%$ of lodging establishments predicted no change in business due to a statewide smoking ban while $34 \%$ of restaurants and $54 \%$ of lodging establishments predicted a decrease in business. ${ }^{87}$

The CRA immediately commissioned a review of the Price Waterhouse report by another accounting firm, Coopers and Lybrand, which said the Price Waterhouse results were biased because the respondents had no previous experience with a statewide smoking ban, so their impressions would not accurately reflect potential business loss. ${ }^{88}$ The survey also biased its results by giving respondents misleading data regarding the scope of areas affected by $A B$ 13. Coopers and Lybrand noted that Price Waterhouse omitted "a key conclusion, if not the key conclusion, that over $61 \%$ of respondents thought that there would be no impact or positive impact on sales from the proposed ban." This prompt response by the CRA neutralised the effects of the Price Waterhouse study.

$\mathrm{AB} 13$ was granted reconsideration on ? June and passed the Assembly 47 to 25 . The tobacco industry had contributed $\$ 363823$ in campaign contributions between 1976 and 1993 to members who voted for $\mathrm{AB} 13$ (average $\$ 7741$ per “yes" vote), and $\$ 711405$ to members who voted against it (averag?

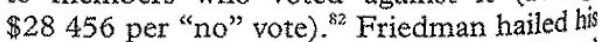
success as a "spectacular turnaround," and attributed the change in votes to "the outpouring of spontaneous public support for $A B{ }^{13}$ all over the state, and the outrage expressed by the voters at the passage of the industry spon: sored measure." Assembly expressed discontent with both $A B$ 13 and $A B$ 996, saying one bill was too strist and the other was not strict enough, and hoped a compromise bill could be created in the stat Senate, or in a conference committee.

THE SENATE HEALTH AND HUMAN SERVICES

COMMITTEE 13 and AB 996 were both assigned to th Senate Health and Human Services Judiciary Committees. AB 996 died in Senate Health and Human Services Comni tee as a result of effective lobbying by tobac control advocates and senators friendly control advocates and senators inght it for a vote, presumably because it did not 
enough votes to pass. ${ }^{\$ 1}$ (The legislation re-emerged in January of 1994 as the "Califor nia Uniform Tobacco Control Act" or Proposition 188, an initiative sponsored by Philip Morris that qualified for California's November 1994 ballot; the voters defeated it, $71 \%$ "no" to $29 \%$ "yes". 93 )

AB 13 passed the Senate Health and Human Services Committee on its second hearing after being further amended to exempt portions of hotel and motel lobbies, bars and gaming clubs, and some convention centres and warehouses. Between the first and second committee hearings, in response to a question from a reporter, Firiedman argued that:

$\mathrm{AB} 13$ creates one uniform protective statewide law and prempts the patchwork of local ordinance around the state with which businesses must currentity comply. It protects all workers from environmental tobacco smoke and all employer from claims related to environmental tobacco smoke. ${ }^{\text {gh }}$ [Emphasis added.]

Once again, these exemptions were created by excluding these venues from $\mathrm{AB} 13$ 's definition of "places of employment". Since AB 13 only applied to places it defined as "places of employment," these exemptions from the smoke free mandate were also exempted from the bill's preemption clause, leaving them open to local regulation. Friedman admittedly accepted the amendments to exempt these areas to move the bill through committee and declared the bill's passage to be a victory against the tobacco industry. ${ }^{\text {1 }}$ In a bulletin to members, the League of California Cities reassured cities that despite exemptions added to the bill, "AB 13 will also be amended to clarify that local governments will not be prevented from enacting stricter local ordinances for the areas excepted by $A B$ 13., ${ }^{395}$ [Emphasis in original.] The American Lung Association told its membership, "These exemptions do not preempt local governments to keep or adopt stricter local smoking ordinances." ${ }^{\prime 96}$ [Emphasis in original.] The $A B 13$ coalition continued to support the bill, despite the fact that it was no longer " $100 \%$," the rationale several members of the support coalition had initially used to justify accepting the preemption language.

\section{THE SENATY JUDICIAR Y COMMITTEB}

After passing the Senate Health and Human Services Committee, $A B 13$ was referred to the Senate Judiciary Committee, chaired by Senator Bill Lockyer (Democrat from Hayward). Lockyer had previously furthered tobacco industry interests by authoring California's tort reform law, the California Civil Liability Reform Act of 1987, which specifically exempted "inherently unsafe" products, such as tobacco, from state civil liability laws."7

Before AB 13's first hearing before the Judiciary Committee, Serena Chen, public affairs officer for the American Lung Association of Alameda County in Lockyer's district, criticised the Senator for his lack of public sup port for $\mathrm{AB} 13,{ }^{98}$ in what she believed to be an off the record briefing with a reporter for the Fremont Argus. ${ }^{99}$ The newspaper ran her comments in a front page story. In response, Lockyer threatened $\mathrm{AB} 13$ by withholding his vote. ${ }^{10}$ Friedman denounced Chen's comments as "slanderous", ${ }^{01}$ issued a press release defending Lockyer, ${ }^{102}$ and dropped the American Lung Association from the AB 13 support coalition. ${ }^{102} \mathrm{He}$ also sent a letter to the editor of the Argus defending Lockyer and stating his belief that $\mathrm{AB} 13$ would receive fair treatment from the Senator. ${ }^{101}$

The $A B 13$ support coalition distanced itself from the controversy and the American Lung Association. In an 18 August 1993 letter to Lockyer from top executives of the American Heart Association, the American Cancer Society, and the California Medical Association, the organisations "disavow [ed] any connection to the [ALA] comments," and informed Lockyer they had encouraged the American Lung Association to discipline "the responsible party" in that organisation. ${ }^{103}$ Friedman later admitted that his actions had been extreme, and expressed "the highest regard for [the AIA] and its statewide leadership."104 Friedman had mollffed a committee chairman whose support was critical to $A B 13$ 's success. Despite the fact it was no longer a member of the $A B$ 13 support coalition, the American Lung Association continued to work with Friedman to pass the bill. Lockyer thanked Friedman for the defence of his character and withdrew his nominal opposition to the bill but stated, "There appears to be some fine tuning that needs to be done." 100

At $A B 13^{3} s$ first hearing in the Judiciary committee, on 19 August 1993, it was clear $A B$ 13 did not have the votes to get out of committee. ${ }^{90}$ Friedman again amended AB 13 to allow smoking in workplace break rooms provided that there was ventilation equipment providing 60 cubic feet per minute per smoker that exhausted air directly outside and that sufficient break rooms existed for non-smokers. The bill was also amended to state that Cal/OSHA would not be involved in enforcing the state law until an employer had been guilty of three violations within one year, as determined by the local enforcement agency. ${ }^{105}$ As violations of anti-smoking laws rarely reach three violations within a year, this amendment effectively precluded state level enforcement of the bill. 16206

Over the next several weeks, Lockyer proposed several amendments that would have weakened the bill's smoke free mandate, including a request that Friedman relinquish his $100 \%$ smoke-free requirement in favour of ventilation standards. Friedman agreed to consider such standards. ${ }^{107}$ Had these proposed amendments been adopted, the bill would have been similar to $A B 996$. Lockyer also proposed exemptions for meeting and banquet rooms, all convention centres, bars in restaurants, preemption of all future local ordinances, increased exemptions for hotel rooms and lobbies, and a hardship exemption for businesses who could prove need. In addition, he developed a scheme that would have allowed smoking in workplace break rooms and restaurants if they were in compliance by 1 January 
1997 with as yet unwritten Cal/OSHA rules to protect non-smokers from environmental tobacco smoke. ${ }^{108}$

After conferring with his support coalition, Friedman answered Lockyer's proposal by expressing concern that the proposed ventilation rules did not specify that smoking would be prohibited should Cal/OSHA fail to develop a protective ventilation standard. ${ }^{109}$ Friedman also protested the proposed hardship exemption "since Cal/OSHA does not grant employers such exceptions for other occupational health or safety standards." 109 Rather than accepting Lockyer's proposal, Friedman petitioned to turn $A B 13$ into a two year bill, allowing him to bring the bill back to committee for discussion in 1994. His request was granted and Friedman vowed to return in 1994 with a stronger support coalition for the bill. ${ }^{104}$

In February 1994, AB 13 was taken up again in the Senate Judiciary Committee. Friedman amended the bill to expand exemptions for hotels and motels to gain the support of the California Hotel and Motel Association, a previous opponent of $\mathrm{AB}$ 13. Friedman also adopted Lockyer's amendment to permit smoking in bars until 1 January 1997, after which the establishment would have to be in compliance with an as yet unwritten ventilation standard deemed acceptable for protecting workers from environmental tobacco smoke by the EPA or Cal/OSHA. However, unlike Lockyer's proposal, if no standard was written by 1 January 1997, smoking would be prohibited in bars and gaming clubs. Friedman's bill also required ventilation equipment in workplace break rooms that permitted smoking to meet the unwritten EPA or Cal/OSHA standards. ${ }^{110}$

$A B 13$ was heard again by the Senate Judiciary Committee on 22 March 1994. Two tobacco friendly amendments were added to the bill. ${ }^{11}$ The first, sponsored by Senator Art Torres (Democrat from Los Angeles), extended the phase in period and ventilation options for bars, gaming clubs, and convention centres to restaurants. Torres had historically supported tobacco control legislation and declared his intention to vote for $\mathrm{AB} 13$ with or without his amendment, ${ }^{112}$ but was influenced by restaurateurs who complained their businesses would be threatened by proposed smoking restrictions. ${ }^{113}$ The amendment was accepted by the committee over objections of Friedman and the CRA, who claimed the cost of ventilation equipment would be prohibitive for small businesses. ${ }^{114}$

The second amendment, sponsored by Senator Charles Calderon (Democrat from Whittier), preempted all future ordinances. Calderon had a history of supporting similar preemption language. ${ }^{115}$ In proposing his preemption amendment to $\mathrm{AB} 13$, Calderon argued that if Friedman truly wanted to establish a state standard for smoking control, he should extend the preemption in the bill to all local ordinances. ${ }^{114}$ Friedman objected that his fragile support coalition would disintegrate because many supporters were philosophically opposed to preemption. ${ }^{114}$ After adding these amendments, the Judiciary Committee passed the bill by 6 to 1 .

Once $A B \quad 13$ was amended to broadly preempt local laws, opposition to it solidified. The League of California Cities, ${ }^{116}$ the American Cancer Society, ${ }^{117}$ the American Lung Association, ${ }^{118}$ and the American Heart Association $^{119}$ expressed opposition to the two pro-tobacco amendments and said they would oppose the bill until both amendments were removed. ANR continued to oppose the bill.

The weakening of $A B 13$ was front page news. ${ }^{120}$ The Los Angeles Times editorial page called the hearing "a rape in Sacramento."12 Friedman lobbied to remove the Torres and Calderon amendments from $A B 13$ in the Senate Appropriations Committee, the last committee before the Senate floor. ${ }^{122}$ Torres, realising he had been misled at the hearing by restaurant owners in his district, worked with Friedman's office to remove the amendment he had suggested as well as Calderon's preemption language. ${ }^{123}$ Friedman and his supporters successfully removed the hostile amendments in the Senate Appropriations committee. The $\mathrm{AB} 13$ support coalition once again backed the bill, while ANR continued to oppose it.

THE SENATE FLOOR

After $A B 13$ passed the Senate Appropriations Committee, it was sent to the Senate floor. Senator Marian Bergeson (Republican from Newport Beach), AB 13's floor manager in the Senate, successfully fought off several hostile amendments. However, one amendment was accepted on 26 June 1994 on the Senate floor smoking areas would be allowed in long tern patient care facilities, and in businesses with fewer than five employees, so long as all ait from the smoking area was exhausted directls outside, the area was not accessible to minoss no work stations were situated within the smoking area, and EPA or Cal/OSHA ventilation standards were met once estab lished. The bill passed the Senate on 30 Jun 1994. The Assembly voted concurrence with the Senate amendments.

Governor Wilson signed the bill into law a 21 July 1994 and it became effective on 1 Janx ary 1995. Restrictions on smoking in bars wet scheduled to take effect on 1 January 1997. June 1996 the legislature passed and the $G_{0}$ ernor signed a bill extending this deadline to January $1998 .{ }^{124}$ )

The final version of the bill retained $100 \%$ smoke-free mandate as well as preemption clause. Amendments were word preemption clause. Amendments were smoke-t mo also mandate that allowed smoking was at exemption from the preemption clause. local entities would be allowed to enforce ing regulations and pass and enforce new lations restricting smoking in areas exemp from $A B 13$, despite its preemption clad Nevertheless, Governor Pete Wilson cited bill's preemption of local ordinances bill's preemption of local ordinand
reason to sign the bill into law. He stated 
protected the health of workers as well as California's businesses because:

by providing a uniform, statewide standard which preempts the patchwork of local ordinances around the state with which businesses must currently comply, the law does not give one business an economic advantage over another business. ${ }^{125}$

The Governor adopted the position advanced by the business community through the CRA.

The Centers for Disease Control and Prevention's analysis of $\mathrm{AB} 13$ also concluded that it was preemptive, ${ }^{9}$ making California one of the 18 states in 1996 in which local clean indoor air legislation was preempted by state legislation.

\section{Discussion}

By bringing together business, labour, local government, and health organisations, Friedman and the $A B 13$ support coalition success fully transformed public sentiment against smoking into statewide legislation. The health agencies were able to disseminate information about the adverse health effects of environmental tobacco smoke, the CRA was able to lend credibility to the fact that state smoking restriction laws do not hurt restaurant business, and the League of California Cities lent support to arguments that the bill would not limit the power of local governments to pass stricter restrictions than those contained in the bill. The coalition also provided critical feedback to Friedman on areas of compromise such as ventilation standards, preemption, and exemptions of certain areas. Equally important, the coalition was able to prevent the tobacco industry from taking control of the bil and passing a blatantly promindustry version under the guise of tobacco control.

However, a consensus among all of California's tobacco control advocates over acceptable compromises-in this case, preemption-was lacking. When the CRA first demanded preemption in any anti-smoking legislation they would support, advocates in Sacramento (American Lung Association, American Heart Association, American Cancer Society) agreed among themselves that the preemption clause was an acceptable compromise for the proposed legislation, because of its $100 \%$ smoke-free mandate. They argued that localities could not pass ordinances that were stronger than $100 \%$ smoke-free, eliminating the need for local control over those areas. Their main goal was to extend a state law as far as possible to provide public protection from environmental tobacco smoke. Players outside Sacramento were not considered relevant. In response to the statement that there was a disagreement within the California tobacco control movement regarding the desirability of AB 13, the ACS's Sacramento Public Issues Office responded, "Organisations that are interested in tobacco control and have Sacramento based lobbying offices were in agreement, and worked together regarding $\mathrm{AB}$ 13."1o Others outside state government disagreed. ANR and others argued that because the state law would automatically supersede any weaker local law, the preemption in the bill served no policy purpose and was an unnecessary risk. The $\mathrm{AB} 13$ support coalition attempted to satisfy opponents to the bill from within the tobacco control community by add ing a severability clause and wording exemptions so to allow some local regulation, but they did not consult with tobacco control allies outside Sacramento when making decisions to accept compromises in the bill

ANR and other opponents of AB 13 within the tobacco control community also believed that the public debate over local ordinances proved to be an efficient community education tool that was crucial to effective implementa tion of new tobacco control laws, and such a debate would be lacking in the implementation of a state law. ${ }^{17} 18$ The crucial policy issue of whether state legislation was desirable at all was not debated during the formative stages of $A B 13$ (that is, when $A B 2667$ was proposed), probably because no one (on either side of the debate within the tobacco control community in California) thought the bill had a serious chance of passing. By the time AB 13 passed its first legislative committee, it was too late to create a consensus among tobacco control adyocates over the broader policy issues raised by the bill.

\section{TSSUES WN MMUEMENTATION}

The preemption compromise that Friedman and the $A B 13$ support colition accepted may have been an important factor in the bill's passage, but ultimately the law must be analysed by the protection it affords California's workers from environmental tobaccs smoke. Thus, while most of the debate regarding $\mathrm{AB} 13 \mathrm{cen}$ tred on compromises regarding preemption and areas covered, compromises regarding enforcement were equally inportant. The evolution of $\mathrm{AB} 13$ 's enforcement provisions (from designating $\mathrm{Ca} / \mathrm{OSHA}$, then local police, then turning responsibility for designating a local enforcement agency to local elected bodies) retained local involvement in tobacco control but did not provide specific guidelines for implementing the law, like those that have been included in contemporaneous local legislation. ${ }^{\text {sa }}$ This ambiguity, combined with uncertainties about exemptions such as bars within restaurants, appears to have created confusion among restaurant owners about the law's meaning and impact on individual businesses. ${ }^{127}$ Moreover, the language added in the Senate Judiciary Committee, stating that the state agency, $\mathrm{Cal} / \mathrm{OSHA}$, is not required to become involved in enforcement until an employer is convicted by local authorities of three violations within a year, precluded any effective state enforcement. ${ }^{106}$ Indeed, after $A B$ 13 passed, the American Cancer Society Sacramento Public Issues Office stated that "AB 13 did not contain state level enforcement."

Early experiences with implementing $A B 13$ suggest that communities with strong local ordinances when $A B 13$ passed have generally been more successful in implementing $A B 13$ 


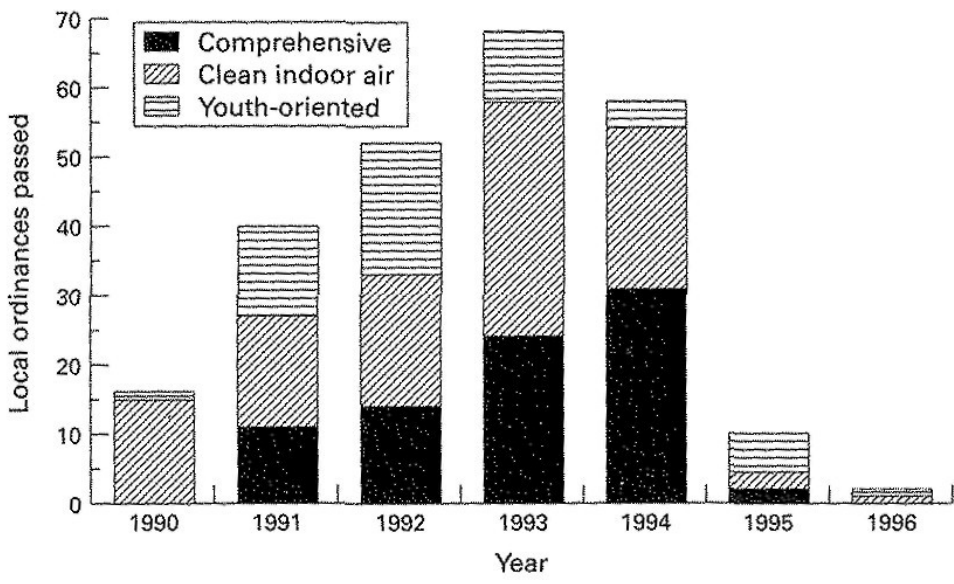

Figure $2 A B 13$ was associated with a dramatic reduction in the passage of local tobacco control ordinances in California, not just in the area of zvorkplace smoking restrictions (which was preempted by $A B$ 13) but also other aspects of clean indoor air, and surprisingly ordinances dealing with markexing and sales of tobacco to children. It appears that efforts to enact clean indoor air ordinances helped create constituencies and coalitions that expanded their focus to include youth oriented issues in comprehensive tobacco control ordinances. Passage of $A B 13$ was associated with an end to this process. Ordinances passed or strengthened during this period were counted. Comprehensive ordinances indicate that clean indoor air and youth oriented provisions were enacted in the same year, generally within the same ordinance. Eight jurisdictions passed two, sequentially stronger, local clean indoor air ordinances during 1990 to 1995 ; both ordinances were counted in the years they were enacted. This graph does not count nine local ordinances (one in 1994 and eight in 1995) that simply designated a local enforcement agency or otherwise implemented $A B 13$. The repeal of stronger ordinances by Santa Monica and Santa Clara are counted as -2 in 1995. (Source: Americans for Nonsmokers'Rights local ordinance database.)

than communities with no history of local tobacco control legislation, or those with no city agency or official willing to take on the responsibility for implementing and enforcing the law. ${ }^{106}$ For example, in the city of Long Beach $^{128}$ and Kern county, ${ }^{129} \mathrm{AB} 13$ was implemented by individuals in the county health department who have taken the law on as their responsibility.

Initial data on the prevalence of exposure of workers to secondhand smoke suggests that, contrary to the hopes of its supporters, AB 13's implementation did not accelerate the trend towards smoke-free workplaces (fig I). Indeed, it was associated with a slowing of the trend toward smoke-free workplaces in California. At the same time that $A B 13$ went into effect, California's anti-tobacco education programmes supported by Proposition 99 were experiencing severe cutbacks, and these cutbacks may have hampered implementation of $A B 13 .{ }^{130}$ Ironically, as discussed below, $A B$ 13 was presented as an alternative to full funding of the Proposition 99 anti-tobacco education programmes.

\section{SECONDARY IMPACTS}

Passage of $\mathrm{AB} 13$ coincided with a dramatic slowing of the rate at which local tobacco control ordinances were enacted in California (fig 2). (Political opponents of smoking restrictions used authorising local enforcement for $\mathrm{AB} 13$ as an opportunity to weaken existing ordinances in two cities, Santa Monica ${ }^{131}$ and Santa Clara.) While it is not surprising that the rate of passage of local workplace smoking restrictions slowed because of a perception that $\mathrm{AB} 13$ made local legislation unnecessary, as well as the preemption in $\mathrm{AB} 13$, it is notable that passage of other tobacco control legislation dealing with issues surrounding tobacco and youth also slowed dramatically. (Most of these ordinances restricted or ended vending machine sales of cigarettes, others restricted tobacco advertising or dealt with youth access issues.) In 1994, the year before $\mathrm{AB} 13$ went into force, 35 local ordinances dealing with youth issues were passed (either as stand alone ordinances or as part of comprehensive local tobacco control ordinances); in 1995 only eight such ordinances were passed (fig 2). In the first quarter of 1996, only one such ordinance was passed. One possible explanation for this is that while the great bulk of local legislative activity dealt with the creation of smoke-free environments, this legislative activity was spilling over into issues related to tobacco and children, particularly through the growing trend towards passage of comprehensive tobacco control ordinances, which included both clean indoor air and youth oriented components. According to Carol Russell, the Chief of Program Services in the Tobacco Control Section at the State Department of Health Services, and the official responsible for implementing community based programmes under Proposition 99:

Another [negative] fallout [from the $\mathrm{AB} 13$ "process"] was that the passage of local public policies around youth and tobacco aiso slowed. We are attempting to give new life to this program direction, but it's difficult. The STAKE Act [a state law] subsequently enacted, deals with enforcement of illegal sales of tobacco to underage youth. This legislation is unlikely to account for the fall off of local policies since youth access is only one part of broader issues, $\mathrm{eg}$, countering pro-tobacco in the community-one of our three program priorities. While everyone is impacted by secondhand smoke, the adult non-smokers in California may not see youth access as their issue, at least one in which they are willing to devote lots of time and energy as they did with environmental tobacco smoke. ${ }^{15}$

The STAKE Act, which only dealt with stale level enforcement issues related to youth access, included specific anti-preemption language designed to protect the rights of com. munities to enact local youth oriented ordinances. The adverse effect on local tobacce control activities dealing with children associated with $A B 13$ was not anticipated bf any parties in the $\mathrm{AB} 13$ debate.

The introduction of $\mathrm{AB} 13$ led to contentious debate within California's tobaca control community. The resulting damage to working relationships within the tobach control community was detrimental to other common tobacco control goals. For examplt the fight over $A B 13$, both between tobact control advocates and against tobacco industr allies who tried to hijack the bill, took attentip away from another high priority: protectil Proposition 99 health education and researt money from the governor and Califor Medical Association, who would prefer ' spend it on medical services. ${ }^{15}$ The legislat 0 ? authorising expenditure of Proposition? funds expired on 30 June 1994, at the height the $\mathrm{AB} 13$ debate. $\mathrm{AB} 13$ dominated tobacco control agenda in California, both terms of resources of the health groups 
also attention by the press and public, ${ }^{132}$ In fact, $A B 13$ was presented as an alternative to full funding of the Proposition 99 anti-tobacco education and research programmes. For example, the Los Angeles Thmes editorial stated: "The continuing diversion of [Proposition 99 Health Education Account] funds is regretta ble, if seemingly unavoidable, but the gains against cigarette smoking ... need not be lost. The best strategy, in our opinion, is passage of $\mathrm{AB} 13$, which would make smoking illegal in most workplaces throughout the state." 133 Perhaps reflecting the fact that AB 13 had displaced Proposition 99 as the central tobacco issue in California at the time, Friedman did not vote for full funding of Proposition 99 antitobacco education and research programmes when the issue came before the legislature. ${ }^{130}$

It is also noteworthy that the tobacco industry did not mount a major campaign against $\mathrm{AB}$ 13. While it did provide some testimony against the bill, including the usual claims of adverse economic consequences, it did not mobilise its smokers' rights groups in a major effort to stop the bill, as it did in other places, such as New York Ciry.

\section{CONCLUSION}

Perhaps AB 13's most important legacy may be its effect on national attitudes towards the issue of preemption in state tobacco control legislation. During the debate over $A B$ 13, opponents of preemption pointed out that state affiliates of the national voluntary health organisations were violating established national policy. However, after the introduction of $\mathrm{AB} 13$, the national policy was amended to include:

Only in those extremely rare instances when we can achieve 100 percent of our goals in a piece of legislation, such as a complete ban on smoking in the workplace and public places, can preemption even be considered ${ }^{33}$

Because preemption now exists in a state antismoking law that is perceived as strong, in future tobacco control debates it may be harder to argue that preemption is bad because it has been a successful tool of the tobacco industry to thwart tobacco control goals. The issue has become less black and white. This ambiguity may stem from the fact that $A B 13^{\text {'s }}$ policies on preemption and the value of state $v$ local ordinances did not arise from a formal proactive debate on these topics within the broad tobacco control community of California, but rather evolved under the pressure of events.

Because of the lack of state implementation and clear local enforcement guidelines, AB 13 has not created a statewide uniform standard for workplace smoking policies. Indeed, the provisions of $A B 13$ which granted local government the authority to enforce the law represent an ironic outcome of the debate over preemption. The CRA's original motivation for insisting on preemption-and the Governor's reason for signing the bill-was to create a "level playing field" in which there was a uniform state standard for regulating smoking in workplaces. The only effective enforcement is at the local level and is left to local discretion, yielding a "patchwork" of local enforcement.

It is important to note that this outcome occurred in California, a state with a strong tobacco control coalition, ${ }^{135}$ one experienced in state political battles by Proposition 99, and a constituency that is well educated about the health hazards of public tobacco use. Given the fact that compromises are part and parcel of the process of enacting state legislation on almost any topic, the supporters of $A B 13$ can iustifiably claim that they obtained the strongest possible state law that mandates protection for almost all workers in California from secondhand smoke. Even so, the question of whether AB 13 effectively advanced the tobacco control agenda in California remains controversial nearly two years after $\mathrm{AB} 13$ was passed. California's experience suggests that the anticipated outcomes for state tobacco control legislation modelled after $\mathrm{AB} 13$ may be even more problematic in states without the strong pro-tobacco control environment that exists in California. In other states that lack a dedicated and effective advocate in the legislature like Friedman, where the state voluntary health agencies are not as strong, or where there is little organised grass roots support for tobacco control activities, it is possible that introduction of a bill as ambiguous as $\mathrm{AB} 13$ will provide the tobacco industry with opportunities to pass weak preemptive state laws. ${ }^{78} 79$

Because its supporters initially doubted that $A B 13$ would pass, there was never an effort to reconcile the differences between state oriented and locally oriented tobacco control policies. This lack of consensus, combined with the political realities inherent in passing any state legislation, led to a bill with ambiguous preemption language and replaced the "patchwork of local laws" with a "patchwork of local enforcement." The history of $\mathrm{AB} / 3$ sug" gests that tobacco control adwocates at all levels in other states need to reach a clear consensus on the question of preemption before the issue arises in the legislature, and they should not simply leave this important policy question to the vagaries of legislative deal making.

This work was supported by National Cancer Institute grant $C A \sim 61021$ and a grant fram the University of California Tobacco-Related Diseases Research Irogram (IRT520). 
Table 1 Comparison of proposed and enacted clean indoor air laws, 1993-1994

\begin{tabular}{|c|c|c|c|c|c|c|c|}
\hline & $\begin{array}{l}A B 2667 \mathrm{Feb}- \\
\text { ruary } 13,1992\end{array}$ & $\begin{array}{l}A B 13 \\
\text { December } 7,1992\end{array}$ & $\begin{array}{l}\text { AB 13 } \\
\text { fune 13,1994* }\end{array}$ & $\begin{array}{l}\text { AB } 996 \\
\text { May 4, } 1994\end{array}$ & $\begin{array}{l}\text { San Francisco } \\
1993^{\star}\end{array}$ & $\begin{array}{l}\text { Davis } \\
1993^{*}\end{array}$ & $\begin{array}{l}\text { Shasta County } \\
1993^{*}\end{array}$ \\
\hline Community & Statewide & Statewide & Statewide & Statewide & Urban & $\begin{array}{l}\text { Mid-sized } \\
\text { city }\end{array}$ & Rural \\
\hline Preemption & None & $\begin{array}{l}\text { Preemption of } \\
\text { local ordinances } \\
\text { regulating } \\
\text { smoking in } \\
\text { piaces of } \\
\text { employment }\end{array}$ & $\begin{array}{l}\text { Preemption of local } \\
\text { ordinances regulating } \\
\text { workplace smoking; exempt } \\
\text { areas are subject to local } \\
\text { control; if the smoke-free } \\
\text { mandate is tampered with in } \\
\text { future, localities retain the } \\
\text { right to enact and enforce } \\
\text { smoking regulations }\end{array}$ & $\begin{array}{l}\text { Preemption of all } \\
\text { local ordinances } \\
\text { regarding tobacco } \\
\text { use or distribution } \\
\text { not in effect by } \\
\text { April } 1,1993\end{array}$ & N/A & N/A & N/A \\
\hline \multicolumn{8}{|l|}{ Workplaces } \\
\hline Common areas & Smoke-free & Smoke-free & Smoke-free & Smoke-free & Smoke-free & Smoke-free & Smoke-free \\
\hline Private offices & Smoke-free & Smoke-free & Smoke-free & $\begin{array}{l}\text { Smoking permitted } \\
\text { with ASHRAE } \\
\text { ventilation }\end{array}$ & Smoke-free & Smoke-free & Smoke-free \\
\hline Cafeteria & Smoke-free & Smoke-free & Smoke-free & $\begin{array}{l}\text { Smoking permitted } \\
\text { in } 25 \% \text { of seating } \\
\text { with ASHRAE } \\
\text { ventilation }\end{array}$ & Smoke-free & Smoke-free & Smoke-free \\
\hline Smoking lounges & Not permitted & Not permitted & $\begin{array}{l}\text { Permitted in businesses with } \\
\text { less than } 5 \text { employees, where } \\
\text { there is consent from all } \\
\text { workers, in areas where no } \\
\text { workers are stationed that } \\
\text { meet OSHAERA ventilation } \\
\text { standards }\end{array}$ & $\begin{array}{l}\text { Permitted with } \\
\text { ASHRAE } \\
\text { ventilation; do not } \\
\text { need to be enclosed } \\
\text { or separately } \\
\text { ventilated }\end{array}$ & Not permitted & $\begin{array}{l}\text { Not } \\
\text { permitted }\end{array}$ & Not permitted \\
\hline Break rooms & Smoke-free & Smoke-free & $\begin{array}{l}\text { Smoking permitted if } \\
\text { equipped with ventilation or } \\
\text { protective equipment and if } \\
\text { others exist for non-smokers }\end{array}$ & Not addressed & Smoke-free & Smoke-free & Smoke-free \\
\hline Conference rooms & Smoke-free & Smoke-free & Smoke-free & $\begin{array}{l}\text { Smoking permitted } \\
\text { with ASHRAE } \\
\text { ventilation }\end{array}$ & Smoke-free & Smoke-free & Smoke-free \\
\hline $\begin{array}{l}\text { Non-retaliation } \\
\text { clause }\end{array}$ & No & No & No & No & No & Yes & Yes \\
\hline \multicolumn{8}{|l|}{ Public places } \\
\hline Restaurants & Smoke-free & Smoke-free & $\begin{array}{l}\text { Smoking permitted in } \\
\text { meeting/banquet rooms } \\
\text { except while food is present or } \\
\text { during an exhibit; nearby } \\
\text { corridors when smoking is } \\
\text { prohibited in meeting/banquet } \\
\text { rooms }\end{array}$ & $\begin{array}{l}\text { Smoking permitted } \\
\text { in restaurants with } \\
\text { less than } 50 \text { seats, } \\
\text { and in } 30 \% \text { of } \\
\text { restaurants with } \\
\text { ASHRAE } \\
\text { ventilation }\end{array}$ & $\begin{array}{l}\text { Smoke-free } \\
\text { with a } \\
\text { hardship } \\
\text { exemption } \\
\text { available after } \\
6 \text { months for } \\
25 \% \text { of seating }\end{array}$ & Smoke-free & Smoke-free \\
\hline $\begin{array}{l}\text { Bar areas of } \\
\text { restaurants }\end{array}$ & Smoke-free & Smoke-free & $\begin{array}{l}\text { Smoking permitted until } \\
1 / 1 / 97 \text {; after } 1 / 1 / 97 \text { smoking } \\
\text { permitted if in compliance } \\
\text { with OSHA/EPA ventilation } \\
\text { standard adopted by } 1 / 1 / 97\end{array}$ & $\begin{array}{l}\text { Smoking permitted. } \\
\text { No restrictions on } \\
\text { location of bar area }\end{array}$ & $\begin{array}{l}\text { Smoking } \\
\text { permitted }\end{array}$ & Smoke-free & Smoke-free \\
\hline Free-standing bars & Smoke-free & Smoke-free & $\begin{array}{l}\text { Smoking permitted until } \\
1 / 1 / 97 ; \text { after } 1 / 1 / 97 \text { smoking } \\
\text { permitted if in compliance } \\
\text { with OSHA/EPA ventilation } \\
\text { standard adopted by } 1 / 1 / 97\end{array}$ & Smoking permitted & $\begin{array}{l}\text { Smoking } \\
\text { permitted }\end{array}$ & Smoke-free & Smoke-free \\
\hline Hotel Bars & Smoke-free & Smoke-free & $\begin{array}{l}\text { Smoking permitted until } \\
1 / 1 / 97 \text {; after } 1 / 1 / 97 \text { smoking } \\
\text { permitted if in compliance } \\
\text { with OSHA/EPA ventilation } \\
\text { standard adopted by } 1 / 1 / 97\end{array}$ & Smoking permitted & $\begin{array}{l}\text { Smoking } \\
\text { permitted }\end{array}$ & Smoke-free & Smoke-free \\
\hline Hotel guest rooms & Smoke-free & Smoke-free & $\begin{array}{l}\text { Smoking permitted in } 65 \% \text { of } \\
\text { rooms }\end{array}$ & $\begin{array}{l}\text { Smoking permitted } \\
\text { unless designated } \\
\text { otherwise }\end{array}$ & $\begin{array}{l}\text { Smoking } \\
\text { permitted in } \\
65 \% \text { of guest } \\
\text { rooms }\end{array}$ & $\begin{array}{l}\text { Smoking } \\
\text { permirted in } \\
25 \% \text { of } \\
\text { guest rooms }\end{array}$ & $\begin{array}{l}\text { Smoking } \\
\text { permitted }\end{array}$ \\
\hline Hotel lobbies & Smoke-free & Smoke-free & $\begin{array}{l}\text { Smoking permitted in } \\
25-50 \% \text { of lobby space }\end{array}$ & $\begin{array}{l}\text { Smoking permitted } \\
\text { in up to } 25 \% \text { of } \\
\text { lobby space }\end{array}$ & $\begin{array}{l}\text { Smoking } \\
\text { permitted in } \\
25 \% \text { of lobby } \\
\text { space }\end{array}$ & Smoke-free & Smoke-free \\
\hline Enforcement & CayOSHA & CalOOSHA & $\begin{array}{l}\text { Local agency to be } \\
\text { determined by local governing } \\
\text { body; Deps of Industrial } \\
\text { Relations not required to } \\
\text { respond until 3rd employer } \\
\text { violation within a year }\end{array}$ & $\begin{array}{l}\text { Cal/OSHA is the } \\
\text { sole agency } \\
\text { permitted to } \\
\text { enforce smoking } \\
\text { regulations; } \\
\text { Sheriff's office is the } \\
\text { sole agency } \\
\text { permitted to } \\
\text { enforce youth } \\
\text { access regulations }\end{array}$ & $\begin{array}{l}\text { Director of } \\
\text { public health }\end{array}$ & $\begin{array}{l}\text { City } \\
\text { manager }\end{array}$ & $\begin{array}{l}\text { Local health } \\
\text { department }\end{array}$ \\
\hline Public education & None & None & None & None & None & None & $\begin{array}{l}\text { Public health } \\
\text { department }\end{array}$ \\
\hline
\end{tabular}


Tuble 1 Comparison of proposed and enacted clean indoor air laws, 1993-1994 (Continued)

\begin{tabular}{|c|c|c|c|c|c|c|c|}
\hline & $\begin{array}{l}A B 2667 \text { Feb } \\
\text { rasay } 13,1592\end{array}$ & $\begin{array}{l}\text { AB 13 } \\
\text { Decamber } 7,1992\end{array}$ & 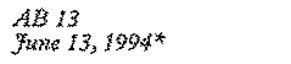 & $\begin{array}{l}\text { AB } 996 \\
M \text { oy } 4.1994\end{array}$ & $\begin{array}{l}\text { Sen Francisco } \\
1993^{*}\end{array}$ & $\begin{array}{l}\text { Daris } \\
1993^{*}\end{array}$ & $\begin{array}{l}\text { Shasta Coumty } \\
1993^{*}\end{array}$ \\
\hline Regutired Signs & $\begin{array}{l}\text { No Smoking } \\
\text { signs required } \\
\text { at workplace } \\
\text { entrances }\end{array}$ & $\begin{array}{l}\text { No Smoking } \\
\text { sigms regunired at } \\
\text { wotiplace } \\
\text { entrances }\end{array}$ & $\begin{array}{l}\text { Signs required matking } \\
\text { smoking and nonsmoking } \\
\text { areas }\end{array}$ & $\begin{array}{l}\text { Signs required } \\
\text { marking smoking } \\
\text { from nonsmoking } \\
\text { ateas, and outlining } \\
\text { law against tobacco } \\
\text { sales to mincrs }\end{array}$ & $\begin{array}{l}\text { No Smoking } \\
\text { signs posted at } \\
\text { workplace } \\
\text { entrances }\end{array}$ & $\begin{array}{l}\text { No } \\
\text { Smoking } \\
\text { signs } \\
\text { required in } \\
\text { nonsmoking } \\
\text { areas }\end{array}$ & $\begin{array}{l}\text { No Smoking } \\
\text { signs required } \\
\text { conspicuously } \\
\text { displayed in } \\
\text { nonsmoking } \\
\text { areas }\end{array}$ \\
\hline Tobacko taxes & None & None & None & $\begin{array}{l}\text { Undefined taxes to } \\
\text { be added duxing } \\
\text { the Budiget Acs of } \\
1993\end{array}$ & None & None & None \\
\hline $\begin{array}{l}\text { Wuth atess } \\
\text { Vending machines }\end{array}$ & Not addressed & Not addressed & Not adiaressed & $\begin{array}{l}\text { Permitred with } \\
\text { ineffective locking } \\
\text { devices; no } \\
\text { restrictions in } \\
\text { adult-only "areas }\end{array}$ & Not addressed & $\begin{array}{l}\text { Not } \\
\text { addressed }\end{array}$ & Prohibited \\
\hline Tobacco samples & Not addressed & Not addressed & Not addressed & $\begin{array}{l}\text { No restrictions; } \\
\text { overturns local law }\end{array}$ & Not acdiressed & $\begin{array}{l}\text { Not } \\
\text { addressed }\end{array}$ & Not addressed \\
\hline Selfwservice displays & Not addressed & Not addrassed & Not addressed & $\begin{array}{l}\text { No restrictions; } \\
\text { overnurns local law }\end{array}$ & Not addressed & $\begin{array}{l}\text { Not } \\
\text { addressed }\end{array}$ & Not addressed \\
\hline
\end{tabular}

*Enacted laws 328.

2 Jacobson PD. Letter to Stanton A Glantz. January 24, 1994.

3 Envirommental Protection Agency. Respiratory health effects

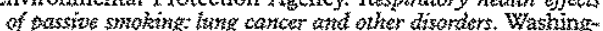
ton DQ: EPA, December, 1992 .

4 Patten $C$. Pierce J, Cavin S, Berry C, Kaplan R. Progress in pretecting non-smokers from environmental fobacco smoke in Callfornia workplaces. Tobaco Comtro 1005; 4 : $139-44$

5 Samuets B, Glanc SA. The politics of local tobacco control. YAMA 1991;266:2110-7.

6 Samuals BE, Begay ME, Hazan AR, Glaniz SA. Bhallip

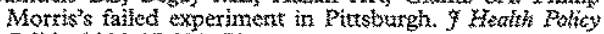
Politics 1992;17:329-51.

7 Traynor MP, Begay ME, Glantz SA. New tobacco industry strategy to prevent local tobacco control. FAMAA 1993: $270: 479-86$.

8 Conlisk E, Siegel M, Lengerich E, MacKenzie W, Malek $S_{\text {, }}$ Eriksen M. The stutus of local smoking regulations in Noth Carolina following a state premption bill. 7 AMA 1995; 273:805-7

9 US Centers for Disease Control and Prevention. Siate tobacco control highlight-1996. Atianta: Centers for Disease Control and Prevention, National Center for Chronic Disesse Prevention and Heath Promotion, Office on Stmoking and Fealth, 1996.

10 Fisher P. Preemption (Memorandum to authors). Wasking" ton, DC: Coalition on Smoking OR Health. September $29,1994$.

11 Pierce JP, Evans N, Farkas AJ, Cavin SW, Berry C, Kramer $M$, et al. Tobacco use in California. An evaluation of the tobacco control frogram, 1989-1993. La Joll

12 Tobacco Control Section. Are Californians protected from environmental tobacco smolke? A summary of findings on worksite and household policies: California adult tobacco survey. Sacramento, CA, Calfornia Department of Yreath Services. September, 1995.

13 Tobacco Control Section. is smoking prohibited in work areas? Sacramenko, CA: California Department of Healt Services. June 11,1096 .

14 Bal DG, Kiser KW, Felten PG, Mozar HN, Nimeyer D. Reducing tobacco consumption in California: develop-
ment of a statewide antimabacco use campaign. $7 A M A$ 1990; $264: 1570-4$

15 Russell C. Letter to Stankon A. Glantz Sacraneno, California: Department of Kealth Services Tobacco Con" trol Section. June 6,1996

16 American Cancer Society Public Issues Office. American Cancer Sockety input, Proposition 188 Report, Glantz [letter]. Sacramento, CA: American Cancer Society, Catifornia Division. December 27, 1995 .

17 ANR. Background paper: Recipe for a smoketree society. Berkeley, Calffornia: Americans for Nonsmokers' Rights, 1993.

18 Alvarez B. Letter to Assembly Member Terry Friedman. March 2, 1993.

19 Pierce $P$. Shaniss $T G$, Pertschuk $M$, Gilpin E, Shopind $D$, Johnson $M$, at al. Do smoking ordinances protect non-smokers from environment

20 t.auria T. Conversation with authors. Marcla 16,1995

21 Leonard K. Conversation with authors. February 2,1994

22 Friedman T. Letter to Feather Macdonald, February 14, 1994.

23 Glantas. Achieving a smokefrea society, Cikndation 1987 ; 76: 746-52.

24 Friedman T. Labor chairman's bill would ban workplace smoking. February 13, 1992
25 American Cancer Society Anerican Heart Association American Lung Association. No time like the present. June $11,1992$.

26 Griffin MJ. Letter to Assembly Membet Friedman. April 3 1092 .

27 Carol I. Interview with authors. February 15, 1994.

28 Pertschuk M. Interview with authors. March 10,1994.

29 Kiser D. Rationale for Support of AB 13 (Friedman) and Information on Cas-Stop. (Memo to Bob Dotye, Lisa Gaspard) Sacramento, California: Atnerican Keart Association. February 16, 1993.

30 California Restaurant Association. Wake up and smell the smoke. Sacramento, California: CRA, May, 2993.

31 California Restaurant Association. Smoking Laws. (CRA Position Statemezts) Sacramento, Callfornia: CRA, june 5,1990 .

32 Gillam . Panel rejects workplace smoking bak. Los Angeles Times 1992 yune 18.

33 Thompson -L. L.erer to Assembiyman Terry Friedman. June 12,1992

34 Friedman T. AB 2667 , as amended Jure 23, 1992

35 Kiser D. Inferview with arthors. January 18, 1994

36 Najera A. Tnterview with atthors. Febrtary 18, 1994

$37 \mathrm{Du}$ Melle F, Davis A, Balin $S$. Alert on tobacco industry-initiated clean indoor air legislation and/or amendments. (Memorandum to State Extecutives, State Public Issue Staff. Washington DC: Tobacco-Free America. Febratry 14, 1989

38 Friedmat T. Letter to Teresa Velo. February 22,1993

39 Abate B, Naiexa T. Clarifyng Assembly Binl 13 statewide smokitg ban and urging strong support by all afflizates. (Memorandum to Affiliate Presidents, Affiliate Executive Directors, Other interested Parties.) Sacramento, California: Anerican Iung Association. 1903 .

40 Velo $\mathrm{T}$. Interview with authors. January 18,1994 .

41 Americans for Nousmokers' Rights (Berkeley, Californis) Position on $A B$ 2667: Neurral. (Position Statement) Juxe 17,2902 .

42 Ennix $C$, Abate $B$, Edmiston WA, Yamasaki $G$, Cortin RF Memorandum to Interested Parties, Sacramento, Califor nia: Kealth Groups Supporting AB 13: American Cancer Society, American Iang Association, American Heart Association, California Medical Association, 1993.

43 Burastero AM. Letter to Terry Friedman. April 9, 1992.

44. Assembly Committee on Labor and Employmert. Commisree Analysis: $\mathrm{AB} 13$ (T. Friedman ary 22,1993 . Sacramento, Calfornat March $3,1993$.

45 Sweeney IT. Wide ranging smoking ban clears hurdics. Santa Monica (Califormia) Outlook 1993 March 10

46 Carol $J$, Pertschuk $M$. Letter to Assembly Member Friedmazk. December 12,1092

47 Bium A. Jetter to Mark Pertschuk, Julia Carol, Americans for Nonsmokers' Rights Board Motnbers. June 9, 1993 1993.

$48 \mathrm{McF}$ (n) $\mathrm{C}$. Letter to Asscmblymember Terry Eriedman. August 23, 1993.

49 Snider JR. Letter to Assemblyman Larry Bowlex. March 12 1993.

50 Tommald 1. Assembly Labor and Employment Conminter Republican Anatysis. Sacramento, California: March 1 1993.

51 Friedman T. $A B$ 13, as amended February 22, 1993. March 18,1993

52. Friedman T. AB 13, as amended April 12, 1993

53 Hunter $Y$. Interview with authors. February $4,1994$.

54. Funter $Y$ Letter to Assembiynember Terry Friedman. May 3.1903

55 Benson $L$. Artached economic impact study and subsequent print and electronic press coverage regarding proposed $100 \%$ smoking tyan. (Metnorandum to Members of the 
California Senate.) Los Angeles, California: Southern n, June 16, 1993 .

56 Levin M. Study halts bid to curb smoking. Los Angeles Times 1992 June 18

57 Jacobs J. Public health vs tobacco money. Sacramento (California) Bee 1994 March 17.

58 Morain D. Legislature Aims Fusillade of Bills at Tobacco Industry, Los Angeles Times 1993 March 10

59 ASHRAE. ASHRAE Standard 62-1989: Ventilation for acceptable indoor air quality. American Society of Heating, Refrigeration, and Air Conditioning Engineers. 1989.

60 Forster J, Hourigan ME, Kelder S. Locking devices on cigarette vending machines: evaluation of a ciry ordinance. $A m$ of Public Health 1992; 82: $1217-9$.

61 Kotz K, Forster J, Kloehn D. An evaluation of the Minnesota State law to restrict youth access to tobacco. 2 Miller J. Staff Analysis of Assembly Bill 996 (Tucker) as amended May 4, 1993. Sacramento, California: Senate amended May 4, 1993. Sacramento, California: Senate 1993.

63 Ellena $N$. Statewide smoking ban bill gets hearing by Assembly panel. Chico (California) Enterprise Record 1993 March 24.

64 Tucker's odorous tobacco bill [editorial]. Sacramento Bee 1993 April 27

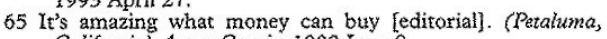
California) Argus-Courier 1993 June 8.

66 Morain D. Assembly bill curbs LA's smoking ban. Los Angeles Times 1993 June 4.

67 Morain D. Panel passes competing tobacco bills. Los Angeles Times 1993 May 20.

68 Morain D. Rival smoking measures stall in assembly. Los Angeles Times 1993 June 2 .

69 Harrison S. Assembly reverses smoke vote. Woodland Hills (California) Daily News 1993 June 8.

70 Alameda Times Star. Tobacco lobby choked up over Assembly about-face. Alameda Times Star 1993 June 14

71 Matthews I. Senate panel switches, OKs smoking limits bil. Sacramento (California) Bee 1993 July 15.

72 Scott J, Waltman N. Interview with authors. March 1, 1994. Tobacco Education and Control Program. Action alert update. Ventura, California: Ventura County Public Health Program, May 14, 1993

74 Ray EV. Letter to Jeanne Scott. May 14, 1993

75 Smith SL. Smoke and mirrors: the tobacco industry makes its play in California. Sacramento (California) News of Review 1993 May 27.

76 Friedman T. Letter to Stanton A Glantz. January 10, 1994. 77 Friedman T. Letter to Stanton A Glantz. January 27, 1994. Siegel $M$. Lerter to Assemblyman Terry B Friedman. Janu-
ary 31,1994 .

79 Pierce J. Letrer to Assemblyman Terry B Friedman. February $1,1994$.

80 Farquhar JW Letrer to Dian Kiser. April 21, 1994.

81 Morain D. Support for tobacco bill goes up in smoke. Los Angeles Times 1993 June 3.

82 Begay ME, Traynor M, Giantz SA. The twuilight of proposition 99: reauthorization of tobacco education programs and tobacco industry political expenditures in 1993. University of CaliforMarch, 1994.

83 Spears L. Assembly OK's bill to snuff out smoking bans. Contra Costa Times (Walnut Creek, California) 1993 June $4: 1$.

84 McCormick E. Tobacco money tied to smoke bill vote. San Francisco Examiner 1993 June 4: A21-4.

85 Glantz SA, Smith LRA. The effect of ordinances requiring smoke-free restaurants on restaurant saies. Am 7 Public Health 1994;84:1081-5.

86 Anon. Public interest pretenders. Consumer Reports 1994; May: 316-20

87 Price Waterhouse. Potential economic effects of a smoking ban in the State of California. May, 1993.

88 Coopers \& Lybrand. Letter to Stanley R Kyker. June 29, 1993

89 Morain D. Assembly OK's tough anti-smoking bill it rejected earlier. Los Angeles Times 1993 June 8: A 3-27.

90 Miller J, consultant to California State Senate Health Com mittee. Interview with authors. January 14, 1994.

91 Wiley $G$, Legisiative Consuitant. Place Published: Pub-

92 Philip Morris. California Uniform Tobacco Control Act,

93 Macdonald $H$, Aguinaga S, Glantz S. The defeat of Philip Morris' "California Uniform Tobacco Control Act". Am $\mathcal{F}$ Public Health 1997. In press.

4 Brady DE. Bartle over smoking is heating up. Los Angeles Thes

95 League of California Cities. Legislative Bulletin No 25-1993. Sacramento, California: July 16, 1993.
96 American Lung Association. Proposed smoking ban lives on, ALAC continues to support $A B$ 13. (Action Alert) Sacramento, California: American Lung Association, July 15,1993 .

97 Glastris P. Frank Fat's napkin: how the trial lawyers (and the doctors!) sold out to the tobacco companies. The Washing ton Monthly 1987 December: 19-25.

98 Stone-Norman L. Lockyer panel to weigh smoking bans. The Argus (Fremont, California) 1993 August 17.

99 Chen S. Interview with authors. January 19, 1994

100 Stone Norman L. Lockyer threatens no-smoking bill. The Argus (Fremont, California) 1993 August 19.

101 Frjedman T. Letter to the editor. The Argus (Fremont, California) 1993 August 19.

102 Friedman T. Friedman drops sponsor of smoking measure. [Press release.] Sacramento, California: August 17, 1993.

103 Tillman DB, Thompson S, Yamasaki $G$, Williams $R$. Letter to Senator Bill Lockyer. August 18, 1993.

104 Scott S. Is Terry Friedman giving away too much. California fournal Weekly 1993 September 6.

105 Fxiedman T. AB 13, as amended August 19, 1993.

106 Klink A. Comments on the "Issues in Implementation" section of your AB 13 paper. [Lerter to S Glantz.] Sacra-
mento, CA: California Healthy Cities Project. June 3, 1996.

107 Friedman T. Possible amendments. [Memorandum to $A B$ 13 supporters.] Sacramento, California: August 25, 1993.

108 Friedman T. New proposal. [Memorandum to AB 13 sup porters.] Sacramento, California: September 3, 1993.

109 Friedman T. Letter to Senator Bill Lockyer. September 3 1993.

110 Friedman T. AB 13, as amended March 7, 1994.

111 Friedman T. AB 13, as amended April 6, 1994

112 Torres A. Letter to the editor. Los Angeles Times 1994 April

113 Associated Press. Sen. Torres Backtracks On Smoking Amendment. San Francisco Chronicle 1994 April 12.

114 Senate Judiciary Committee. Senate Judiciary Committee Hearing. Sacramento, California; March 22, 1994.

115 Weintroub DM, Ingram C. Final budget bills stail as Senate tries to aiter measure. Los Angeles Times 1993 June

116 Funter Y. Letter to Terry Friedman. April 14, 1994.

117 American Cancer Society. Position statement. March 23, 1994.

118 American Lung Association. Oppose- $-A B$ is (T Friedman)-workplace smoking. March 23, 1994

. Position statement. March 22, 1994, Chronicle 1994 March 23.

121 A rape in Sacramento. [Editorial.] Los Angeles Times 1991 March 27.

122 Friedman T. Press release: Statement of Assemblyman Terry Friedman on Senate attack on anti-smoking legis tion. Sacramento, California: March 23,1994.

123 Torres A. AB 13 Amendments. April 29, 1994.

124 Lucas G. Assembly OKs delay on smoking ban. San Frat cisco Chronicle 1996 May 21: B1.

125 Wilson GP. Letter to member of Americans for Nonsmokers' Rights. December 21, 1994.

126 Davis (California). Ordinance No 1682, chapter 231 Smoking Control; March 2, 1993.

127 Walden $G$. Controversy swiris on smoking ban law $S$ Francisco Chronicle 1995 date?

128 City of Long Beach Department of Health and Hune Services Ciry of Department of Healtin and Hume Complaint Protocol. January, 1995

$129 \mathrm{Kern}$ County Department of Public Health. Tobacco fite

130 Monardi F, Balbach E, Aguinaga S, Glantz S. Shifting al giances: tobacco industry political expenditures in Calito nia, January 1995-March 1996. San Francisco, Calim Cit CSF Institute for Health Pol. and City Council. January 10, 1995.

132 Scott S. Harmonic convergence: tobacco wars open of several fronts in 1994. California fournal Weekly March 28:3,7.

133 The little engine that could. [Editorial.] Los Angetes Tt: 1994 May 16.

134. Coalition on Smoking OR Heaith News from to coalition. Washington, DC: American Heart Assocalate September, 1993.

135 Jacobson PD, Wasserman J, Raube K. The political en tion of anti-smoking lesislation. Santa Monica, Callo tion of anti-smoking legis

136 Reynen D. ETS exposure data. [Letter to S Gias Sacramento, CA: California Department 1996. 